\section{Changes in delay of reinforcement in simple instrumental conditioning*}

\author{
JAMES H. McHOSE and LYNN TAUBER \\ Southern Illinois University, Carbondale, Ill. 62901
}

Thirty-two food-deprived albino rats received 30 preshift and 48 postshift trials in a runway apparatus. The design of the experiment was a 2 by 2 factorial manipulation of preshift and postshift delay of reinforcement. The results indicated that increases in reward delay resulted in depression effects, while decreases in reward delay produced no contrast (elation) effects.
Previous studies have repeatedly demonstrated a depression effect attending uncued shifts from large to small reward in instrumental conditioning (cf. Black, 1968). While there are functional and theoretical precedents for treating delay and amount of reward as joint determinants of the same theoretical construct (Amsel, 1958; Capaldi, 1967), the effects of increases in reinforcement delay have apparently received little recent attention. Spence (1956) and his coworkers found no evidence of depression effects attending shifts from short to long delays, nor did Shanab (1971). However, Shanab \& McCuistion (1970) did report a substantial depression effect attending delay increases. The present study provides further information on the effects of uncued changes in delay of reward.

$$
\text { METHOD }
$$

The Ss were 32 naive male albino rats, approximately 90 days old at the beginning of the experiment, obtained from the Holtzman Co., Madison, Wisconsin.

The apparatus was a straight runway consisting of a $30-\mathrm{cm}$ startbox, a $72-\mathrm{cm}$ alley section, and a $38-\mathrm{cm}$ goalbox (GB). The interior height and width of all sections were 9 and $10 \mathrm{~cm}$, respectively. An opaque, solenoid-operated start door separated the start and alley sections of the apparatus, and a transluscent retrace door separated the alley from the GB. Photocell circuitry provided for traversal times over three successive $30-\mathrm{cm}$ lengths, starting at the startbox end of the alley.

Interruption of the last photocell initiated a timer, providing for manipulation of the delay of reinforcement parameter. A Rotron Model WHA2 exhaust fan, mounted to the exterior rear wall of $G B$, extracted air from the apparatus via 1/8-in. holes drilled in the rear wall of GB.

*Supported by Research Grant NSF-GB30510 from the National Science Foundation.
Ten days prior to the first day of training (Day 11), Ss were placed on a 23-h food-deprivation schedule maintained throughout the experiment. On Days 2-10, Ss were individually handled for approximately 2 min each. On Days 9 and $10, \mathrm{Ss}$ were placed in the apparatus and allowed to explore the start and alley segments of the apparatus for approximately $1 \mathrm{~min}$, and approximately $1 \mathrm{~g}$ of $45-\mathrm{mg}$ Noyes pellets, identical to the subsequent reinforcement pellet, was incorporated in Ss' daily ration.

Eight Ss were assigned randomly to each cell of a 2 by 2 factorial design with two preshift (10 and 30 sec) and two postshift (10 and $30 \mathrm{sec})$ of five $45-\mathrm{mg}$ pellets. All Ss received 30 trials in the preshift period, followed by 48 trials of postshift training. Three trials per day were administered to squads composed of two Ss from each group. All Ss within a squad received their first trial of the day before any $S$ received its second trial, etc. This procedure resulted in an intertrial interval of approximately $6 \mathrm{~min}$. On each trial, the startdoor was opened after $S$ had oriented toward the door for 2 sec, and $S$ was removed from the apparatus only after consuming the food pellets in GB.

RESULTS AND DISCUSSION

Since the four recorded responses measured yielded essentially redundant information, the four times for each $S$ on each trial were totaled and reciprocated, yielding a total speed measure. Group mean total speeds are presented in Fig. 1. The first data point (A) represents terminal acquisition or preshift speeds (Trials 19-30) for each group, while each successive trial block contains the data for six trials. As may be seen in Fig. 1, short delay produced faster acquisition speeds than did long delay. The shift from short to long delay (Group 10-30) resulted in slower speeds in the later stages of the postshift period than occurred with continued long conditions of delay prior to the receipt

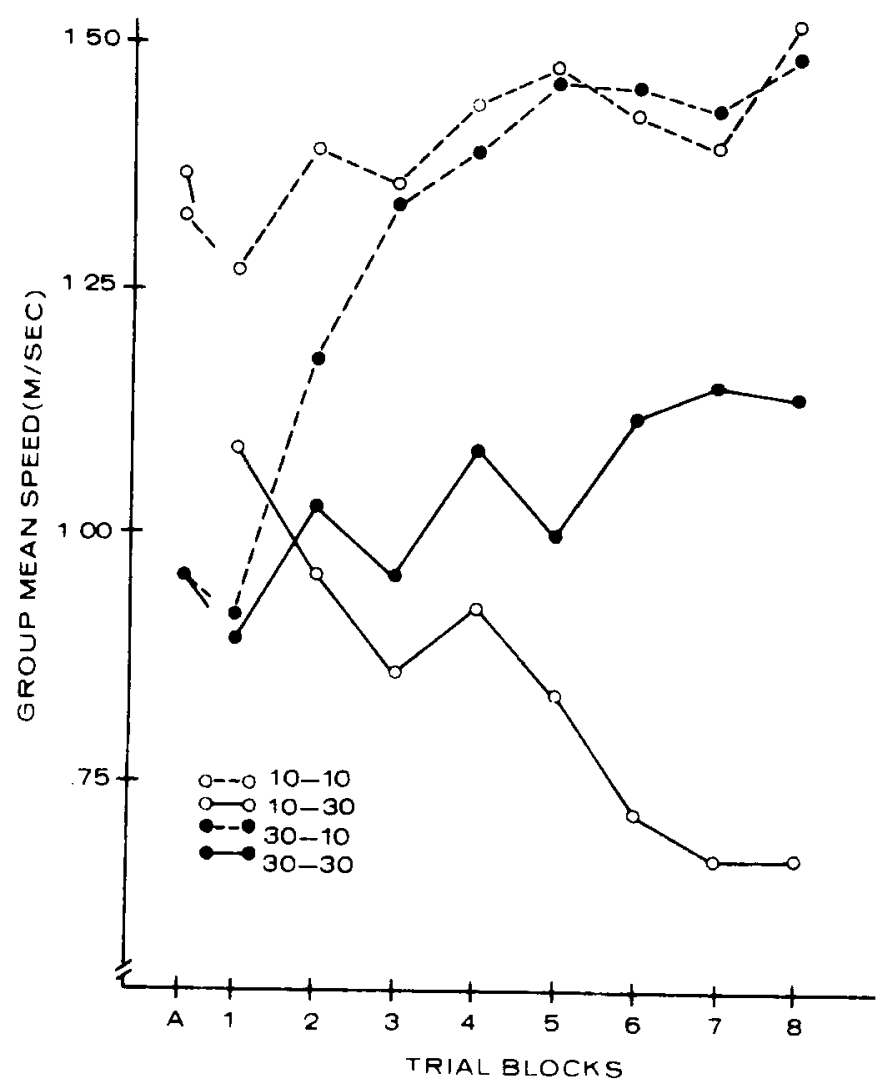

Fig. 1. Group mean total speeds as a function of trial blocks. 
delay (Group 30-30), whereas Ss shifted from long to short reward delay (Group 30-10) eventually displayed performance levels comparable to those evidenced by the unshifted short delay (10-10) condition. Statistical analyses support these conclusions. A Preshift Delay by Postshift Delay by Blocks (A vs 2-3) yielded a significant Preshift by Blocks interaction, $\mathrm{F}=19.75, \mathrm{df}=1 / 28$, $\mathrm{p}<.01$. A subsequent contrast comparison of Groups 10-30 and $10-10$ to Groups $30-30$ and $30-10$ was significant at Block $A$, but not at Blocks 2-3. A similar analysis over Blocks 2-3 and 7-8 yielded a significant Preshift by Postshift by Blocks interaction, $F=4.53, \mathrm{df}=$ $1 / 28, p<.05$, which reflects the fact that the Preshift by Postshift effect, $F$ $=14.48, \mathrm{df}=1 / 28, \mathrm{p}<.01$, varied with the stage of postshift training. More specifically, as indicated by pair comparisons (Tukey A), Group 10-30 ran significantly $(\alpha=.01)$ more slowly than Group $30-30$ at Blocks $7-8$ but not at Blocks 2-3, while Groups 10-10 and $30-10$ did not differ at either Blocks 2-3 or Blocks 7-8.

The present results clearly demonstrate that uncued increases in reward delay depress performance relative to that displayed by Ss trained and maintained on long delay of reward. In this respect, the present findings are in accord with those reported by Shanab \& McCuistion (1970) and at odds with other results (Shanab, 1971; Spence, 1956). Previous failures to obtain such depression effects probably reflect mininicl variation in delay values from pre- to postshift periods (Spence, 1956) or foreshortened postshift training (Shanab, 1971). The observed depression effect in the present study is analogous to the preponderance of magnitude shift data (cf. Black, 1968), and this supports theoretical formulations which treat delay and amount of reward in comparable theoretical fashion (e.g., Amsel, 1958, Capaldi, 1967). Similarly, the absence of positive contrast (or an "elation effect") in the present data is consistent with the typical findings in the magnitude shift literature (cf. Black, 1968). Finally, it should be clear that the present experiment does not in any fashion allow a test of the various interpretations of the effects of changes in reinforcement parameters. Rather, the present data merely suggest that whatever theoretical formulation eventually proves most satisfactory in the treatment of the reward amount variable may also be applied to the reward delay variable.

\section{REFERENCES}

AMSEL, A. The role of frustrative nonreward in noncontinuous reward situations. Psychological Bulletin, 1958, 55, 102-119.

BLACK, $R$. W. Shifts in magnitude of reward and contrast effects in instrumental and selective learning: A reinterpretation. Psychological Review, $1968,75,114-126$.

CAPALDI, E. J. A sequential hypothesis of instrumental learning. In $\mathrm{K}$. W. Spence and J. T. Spence (Eds.), The psychology of learning and motivation. Vol. 1. New York: Academic Press, 1967.

SHANAB, M. E. Positive transfer between delay and nonreward. Journal of Experimental Psychology, 1971, 91. 98-102.

SHANAB, M. E. \& McCUISTION, $S$ Effects of shifts in magnitude and delay of reinforcement upon runway performance in the rat. Psychonomic Science, 1970, 21, 264-266.

SPENCE, K. W. Behavior theory and conditioning. New Haven: Yale University Press, 1956. 